\title{
Detection of Salmonella spp. in exotic pigeons of North Kerala and its antibiogram
}

\author{
Maria Elsa Mathews ${ }^{1}$, R. L. Rathish ${ }^{2}$, P. M. Deepa ${ }^{3}$, K. Vijayakumar ${ }^{4}$ and Lijo John $^{5}$ \\ Department of Veterinary Epidemiology and Preventive Medicine, \\ College of Veterinary and Animal Sciences, Pookode, Wayanad 673 576, \\ Kerala Veterinary and Animal Sciences University, Kerala, India.
}

Citation: Mathews, M. E., Rathish, R. L., Deepa, P. M., Vijayakumar, K. and Lijo John. 2021.Detection of Salmonella in exotic pigeons of North Kerala and its antibiogram. J. Vet. Anim. Sci. 52 (3): 228 233. DOI: https://doi.org/10.51966/jvas.2021.52.3.228-233

Received: 13.01.2021

Accepted: 08.03.2021

Published: 30.09.2021

\begin{abstract}
Pigeon breeding has transformed from being a mere hobby to becoming established as an industry. The increased trade of pigeons inadvertently invites the risk of dissemination of infections including zoonoses like salmonellosis. Pigeons once infected remain carriers for life. This coupled with the ability of the organism to acquire antimicrobial resistance makes salmonellosis, particularly from pigeons an important, public health risk for pigeon handlers. Cloacal swabs from a total of 200 exotic pigeons belonging to 24 lofts from Northern districts of Kerala were collected and attempted to isolate Salmonella and understand its antimicrobial resistance profile. Five isolates of salmonella could be obtained from four of the lofts studied. A prevalence of 2.5 per cent was identified for salmonellosis with 16.67 per cent of the lofts affected. Antimicrobial sensitivity based on disk diffusion assay revealed that all the five isolates were sensitive to amoxicillin-clavulanate and all were resistant to tetracycline and streptomycin. Sixty per cent of the isolates were sensitive to co-trimoxazole, chloramphenicol, ampicillin, cefoperazone, amikacin and gentamicin.
\end{abstract}

Keywords: Salmonellosis, exotic pigeons, antibiogram

Pigeon breeding requires minimal investment for housing, feed cost and veterinary care and its reproduction management is comparatively easy. These factors along with high sales return makes pigeon breeding a lucrative business and a sustainable entrepreneurship. Increasing volume of pigeon trade has resulted in increased trading of birds across the countries, which inadvertently invites the risk of dissemination of infections including zoonoses. Salmonellosis is one such common disease that gets traded along with pigeons. Pigeons once infected could remain as lifelong carriers. People who handle the infected stock can easily acquire the infection from

${ }^{*}$ Part of M.V.Sc. thesis submitted by the first author to Kerala Veterinary and Animal Sciences University, Pookode, Wayanad, Kerala

1. M.V.Sc. scholar: email:mariamathews9497@gmail.com Ph. 7306150939

2. Assistant Professor and corresponding author email:rathish@kvasu.ac.in Ph. 9387387023

3. Assistant Professor and Head i/c

4. Professor and Head

5. Assistant Professor Dept. of Veterinary Biochemistry

Copyright: ( ) 2021 Maria et al. This is an open access article distributed under the terms of the Creative Commons Attribution 4.0 International License (http://creativecommons.org/licenses/by/4.0/), which permits unrestricted use, distribution, and reproduction in any medium, provided the original author and source are credited. 
pigeons. Salmonellosis is a major threat from the public health perspective as the organism is notorious in acquiring antimicrobial resistance (Arcangioli et al., 1999). Antimicrobials are extensively used in pigeon breeding industry to improve the performance and health of the birds. Unscrupulous and unsupervised use of antimicrobials can induce a drug induced selection pressure that results in the evolution of multiple drug resistant bacteria. Studies are lacking regarding the prevalence of salmonella among fancy pigeons in India, particularly in Kerala. Lack of systematic studies adds to the knowledge gap that exists regarding the occurrence and prevalence of multiple drug resistant Salmonellae among domestic pigeons in the state.

\section{Materials and methods}

A total of 200 cloacal swabs of exotic pigeons were collected as per García et al. (2011) from 24 different pigeon lofts from the Northern Districts of Kerala namely, Kannur, Kozhikode, Wayanad and Malappuram. Loft owners were interviewed to understand the antimicrobials used in the respective lofts. Samples were collected aseptically in buffered peptone water and incubated at $37^{\circ} \mathrm{C}$ for 24 hours followed by selective enrichment in Rappaport-Vassiliadis (RV) broth at $42^{\circ} \mathrm{C}$ for 24 hours. Plating was done on Salmonella Shigella
(SS) agar, Xylose Lysine Deoxycholate (XLD) agar, Brilliant Green Agar (BGA) plates at $37^{\circ} \mathrm{C}$ The resultant colonies were analysed after 24 to $48 \mathrm{~h}$.

Biochemical tests of the isolated Salmonella spp. were done according to the standard protocols (Edward and Ewing, 1986). Salmonella was identified based on colony morphology, Gram staining characters and biochemical tests viz. catalase test, oxidase test, IMViC test, urease test and Triple Sugar Iron (TSI) agar test.

Antibiogram of the salmonella isolates were studied using disc diffusion (HiMedia) technique (Bauer et al., 1966) using amikacin $(30 \mu \mathrm{g})$, amoxicillin-clavulanate $(20 / 10 \mu \mathrm{g})$, ampicillin $(25 \mu \mathrm{g})$, cefoperazone $(75 \mu \mathrm{g})$, chloramphenicol $(30 \mu \mathrm{g})$, trimethoprimsulphamethoxazole $(1.25 / 23.75 \mu \mathrm{g})$, gentamicin $(10 \mu \mathrm{g})$, streptomycin $(10 \mu \mathrm{g})$ and tetracycline $(30 \mu \mathrm{g})$. The zone of inhibition of bacterial growth around each disc including the diameter of the disc was measured and interpreted as sensitive or resistant by comparing the ranges given by the manufacturer. Polymerase chain reaction was done targeting aadA2, bla ${ }_{C A R B-2}, \mathrm{~cm} / \mathrm{A}$, sull, tet $A$ and tet $R$ which encodes resistance against streptomycin, ampicillin, chloramphenicol, sulfamethoxazole and tetracycline respectively (Table 1, Table 2).

Table 1: Primers used for the molecular characterization of the isolates

\begin{tabular}{|c|c|c|c|c|c|}
\hline $\begin{array}{l}\text { SI. } \\
\text { No }\end{array}$ & Gene & Primer sequence 5'-3' & Protocol & \begin{tabular}{|l} 
Product \\
size (bp)
\end{tabular} & Reference \\
\hline \multirow{2}{*}{1} & \multirow{2}{*}{ aadA2 } & F- GTACGGCTCCGCAGTGGA TGGCGG & \multirow{2}{*}{1} & \multirow{2}{*}{522} & \multirow{4}{*}{$\begin{array}{c}\text { Briggs and } \\
\text { Fratamico } \\
\text { (1999) }\end{array}$} \\
\hline & & R-GCCCAGTCGGCAGCGACA TCCTTC & & & \\
\hline \multirow{2}{*}{2} & \multirow{2}{*}{ bla ${ }_{\text {CARB-2 }}$} & F- CAATGGCAATCAGCGCTTCCCGTT & \multirow{2}{*}{1} & \multirow{2}{*}{639} & \\
\hline & & R- CGCTCTGCCATTGAAGCCTGTGTT & & & \\
\hline \multirow{2}{*}{3} & \multirow{2}{*}{$\mathrm{cmlA}$} & F- CGC CAC GGT GTT GTTGTT AT & \multirow{2}{*}{2} & \multirow{2}{*}{394} & \multirow{6}{*}{$\begin{array}{c}\text { Chen et al. } \\
2003\end{array}$} \\
\hline & & R- GCG ACC TGC GTA AAT GTC AC & & & \\
\hline \multirow{2}{*}{4} & \multirow{2}{*}{ sull } & F-TCA CCG AGG ACT CCT TCT TC & \multirow{2}{*}{2} & \multirow{2}{*}{331} & \\
\hline & & R- CAG TCC GCC TCA GCA ATA TC & & & \\
\hline \multirow{2}{*}{5} & \multirow{2}{*}{ tetA } & F- GCG CCT TTC CTT TGG GTT CT & \multirow{2}{*}{2} & \multirow{2}{*}{831} & \\
\hline & & R- CCA CCC GTT CCA CGT TGT TA & & & \\
\hline \multirow{2}{*}{6} & \multirow{2}{*}{ tetR } & F- CGCTCCTTCGATCCCGT & \multirow{2}{*}{3} & \multirow{2}{*}{260} & \multirow{2}{*}{$\begin{array}{l}\text { Yang et } \\
\text { al.,2001 }\end{array}$} \\
\hline & & R- GCTGCGTTCATCTACAACAGAT & & & \\
\hline
\end{tabular}




\section{Results and discussion}

Among the 200 samples tested, five isolates produced typical colonies with biochemical properties suggestive of Salmonella spp. The isolates formed colourless and transparent colonies with black center in SS agar (Fig. 1A), red colonies with black centre in XLD agar (Fig. 1B) and pink colonies with pink coloration surrounding the media in BGA (Fig. 1C). The findings are in accordance with Rahman et al. (2016) and El-Prince et al. (2019) who also reported similar colony characteristics exhibited by Salmonella spp. in their studies. The biochemical characters of the isolates obtained are in agreement with Rajagopal and Mini (2013) and Rahman et al. (2016) who reported that the isolates of salmonella were gram negative, small bacilli with specific IMViC reaction results (-+-+) as all were found

Table 2. PCR cycling conditions used for the study to be indole negative, methyl red positive, voges-proskaur negative and utilized citrate (Fig. 2). The findings also agree with Sharma et al. (2019) and Ranjbar etal. (2020) who reported that salmonella isolates produced acid butt and alkaline slant in TSI agar slants (Fig. 2).

A prevalence of 2.5 per cent was identified for salmonellosis with 16.67 per cent of the lofts affected. Comparable prevalence was reported by Casanovas et al. (1995) and Perez-Sancho et al. (2020) who reported a prevalence of 1.5 per cent and 4.41 per cent. However, higher prevalence were reported by Hosain et al. (2012) who reported a prevalence of 35.71 per cent and Saifullah et al. (2016) who reported prevalence of 34 per cent. Santos et al. (2020) suggested that samples should be collected every five days to detect the presence of Salmonella spp. due to the intermittent shedding nature of the bacteria.

\begin{tabular}{|c|c|c|c|c|c|c|}
\hline $\begin{array}{c}\text { Protocol } \\
\text { No. }\end{array}$ & $\begin{array}{c}\text { Initial } \\
\text { denaturation }\end{array}$ & Denaturation & Annealing & Extension & $\begin{array}{c}\text { No. of } \\
\text { cycles }\end{array}$ & Final extension \\
\hline 1 & $95^{\circ} \mathrm{C}, 5 \mathrm{~min}$ & $95^{\circ} \mathrm{C}, 1 \mathrm{~min}$ & $60^{\circ} \mathrm{C}, 1 \mathrm{~min}$ & $72^{\circ} \mathrm{C}, 1 \mathrm{~min}$ & 30 & $72^{\circ} \mathrm{C}, 10 \mathrm{~min}$ \\
\hline 2 & $95^{\circ} \mathrm{C}, 10 \mathrm{~min}$ & $95^{\circ} \mathrm{C}, 30 \mathrm{sec}$ & $55^{\circ} \mathrm{C}, 1 \mathrm{~min}$ & $72^{\circ} \mathrm{C}, 1 \mathrm{~min}$ & 30 & $72^{\circ} \mathrm{C}, 7 \mathrm{~min}$ \\
\hline 3 & $95^{\circ} \mathrm{C}, 5 \mathrm{~min}$ & $95^{\circ} \mathrm{C}, 1 \mathrm{~min}$ & $48^{\circ} \mathrm{C}, 30 \mathrm{sec}$ & $72^{\circ} \mathrm{C}, 30 \mathrm{sec}$ & 40 & $72^{\circ} \mathrm{C}, 3 \mathrm{~min}$ \\
\hline
\end{tabular}

Table 3. Antimicrobial Sensitivity pattern of the isolates

\begin{tabular}{|c|c|c|c|c|c|c|c|c|c|}
\hline Isolate & C & AMC & AMP & COT & CPZ & TE & S & AK & GEN \\
\hline C1 & $\mathrm{R}$ & $\mathrm{S}$ & $\mathrm{R}$ & $\mathrm{R}$ & $\mathrm{R}$ & $\mathrm{R}$ & $\mathrm{R}$ & $\mathrm{R}$ & $\mathrm{R}$ \\
\hline C2 & $\mathrm{R}$ & $\mathrm{S}$ & $\mathrm{R}$ & $\mathrm{R}$ & $\mathrm{R}$ & $\mathrm{R}$ & $\mathrm{R}$ & $\mathrm{R}$ & $\mathrm{R}$ \\
\hline W1 & $\mathrm{S}$ & $\mathrm{S}$ & $\mathrm{S}$ & $\mathrm{S}$ & $\mathrm{S}$ & $\mathrm{R}$ & $\mathrm{R}$ & $\mathrm{S}$ & $\mathrm{S}$ \\
\hline W2 & $\mathrm{S}$ & $\mathrm{S}$ & $\mathrm{S}$ & $\mathrm{S}$ & $\mathrm{S}$ & $\mathrm{R}$ & $\mathrm{R}$ & $\mathrm{S}$ & $\mathrm{S}$ \\
\hline W3 & $\mathrm{S}$ & $\mathrm{S}$ & $\mathrm{S}$ & $\mathrm{S}$ & $\mathrm{S}$ & $\mathrm{R}$ & $\mathrm{R}$ & $\mathrm{S}$ & $\mathrm{S}$ \\
\hline
\end{tabular}

C- Chloramphenicol; AMC- Amoxicillin-clavulanate; AMP- Ampicillin; COT- Trimethoprim-sulphamethoxazole; CPZ- Cefoperazone; TE- Tetracycline; S- Streptomycin; AK- Amikacin; GEN- Gentamicin; S - Sensitive; R Resistant

Table 4. Antimicrobial resistance genes in the Salmonella isolates

\begin{tabular}{|c|c|c|c|c|c|}
\hline \multirow{2}{*}{ Genes } & \multicolumn{5}{|c|}{ ISOLATES } \\
\cline { 2 - 6 } & $\mathrm{C} 1$ & $\mathrm{C} 2$ & $\mathrm{~W} 1$ & W2 & W3 \\
\hline aadA2 & + & + & - & - & - \\
\hline bla & - & - & - & - & - \\
\hline cARB-2 & - & + & - & - & - \\
\hline sull & + & - & - & + & + \\
\hline tetA & + & + & + & - & - \\
\hline tetR & - & - & - & & + \\
\hline
\end{tabular}




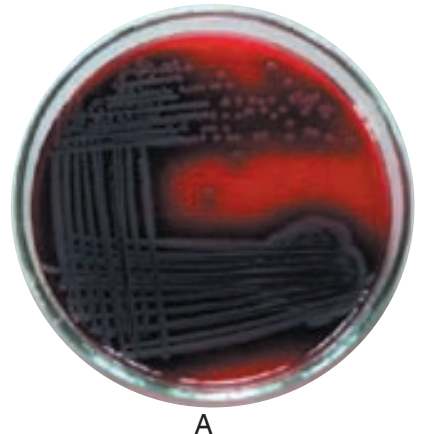

A

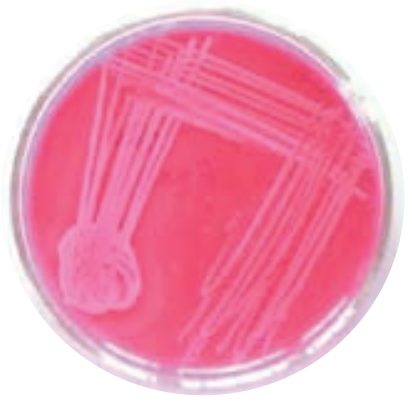

B

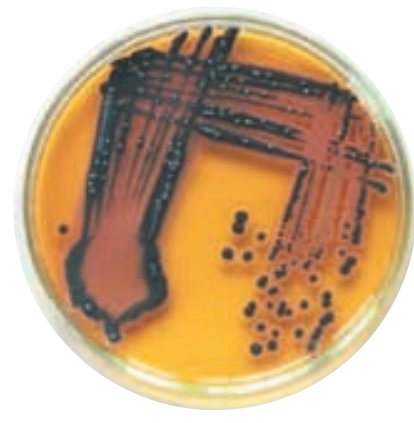

C

Fig. 1. Salmonella isolate on selective Media

A: SS Agar

B: XLD Agar

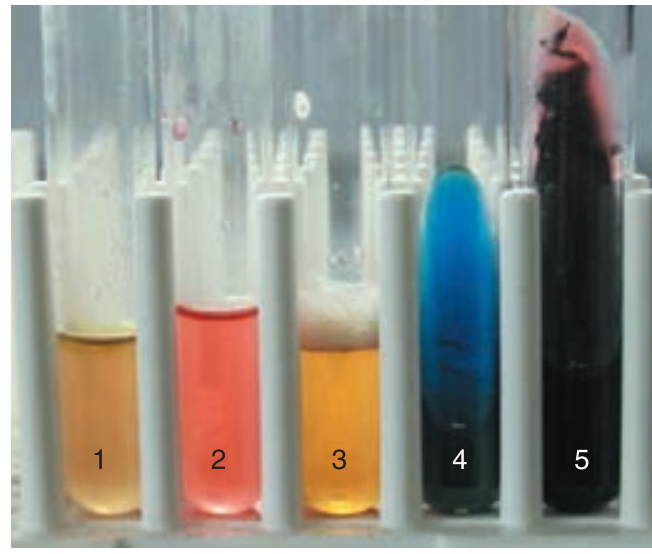

Fig. 2. IMViC test and TSI of Salmonella isolate

1. Indole: Negative 2. Methyl red: Positive

3. Voges- proskauer: Negative

4. Citrate utilisation: Positive

5. Triple Sugar iron with $\mathrm{H} 2 \mathrm{~S}$ production

Similar findings were also reported by Teske et al. (2013). Repeated sampling of all birds in the selected lofts during the present study might have improved the detection rate.

Among the five isolates tested for antimicrobial sensitivity, all (100 per cent) were sensitive to amoxicillin-clavulanate. Three isolates (60 per cent) each was sensitive to chloramphenicol, ampicillin, co-trimoxazole, cefaperazone, amikacin and gentamicin. All isolates were resistant to tetracycline and streptomycin. The details regarding the antimicrobial sensitivity pattern of the isolates are given in the Table 3 .

High sensitivity towards amoxicillinclavulanate was reported by Stenzel etal.(2014). Since none of the lofts surveyed for the present work used amoxicillin-clavulanate, absence of resistance to the drug could be explained to be due to poor selection pressure induced by the drug. The findings also agree with that of Jahantigh and Nili (2010) who reported high level of resistance towards tetracycline among salmonella in pigeons. The varying resistance to antimicrobials among different populations of fancy pigeons could be because of different preferences of antimicrobials being used in different localities (Kaczorek-Lukowska et al., 2020).

Among the six genes tested for detecting antimicrobial resistance, amplification was obtained in three. All of the isolates were positive for tet $A$ gene and produced $831 \mathrm{bp}$ sized amplicons (Fig. 3). The aadA2 gene (522 bp amplicon) was detected in two isolates (40 per cent) (Fig. 4). The clmA gene (394 bp amplicon) was detected in two isolates (40 per cent) (Fig.5). No amplification was obtained

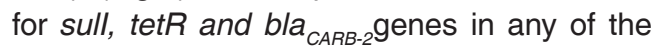
isolates (Table 4).

Kaczorek-Lukowska et al. (2020) reported that tet $A$ gene was among the most common antibiotic resistance genes that were isolated from domestic pigeons. Extensive use of tetracycline could have contributed to the selection of isolates with tetA gene. Yousef and Mamdouh (2016) reported the presence of Class I integrons in Salmonella Enteritidis isolated from pigeons, which was associated with a variety of resistance genes including the $\operatorname{aad} A$. Absence of sul1 gene even in presence of isolates resistant to co-trimoxazole could be because of the involvement of other genes belonging to the sul family (Kozak et al., 2009 Xu et al., 2020). 


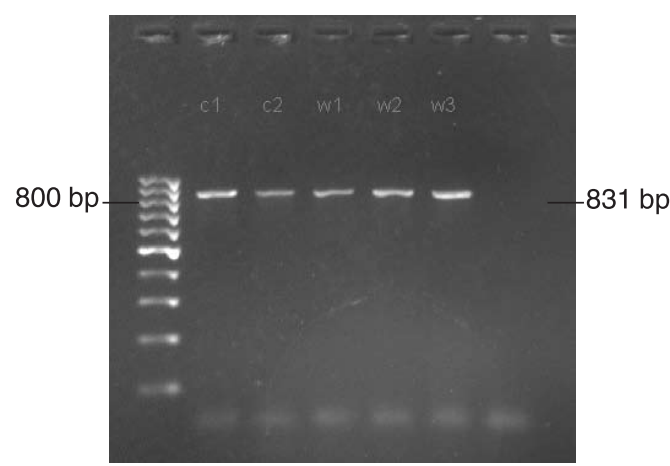

Fig. 3. Agarose gel electrophoresis of tetA specific PCR

Lane1: DNA marker 100bp

Lane 2-6: Positive samples (831 bp)

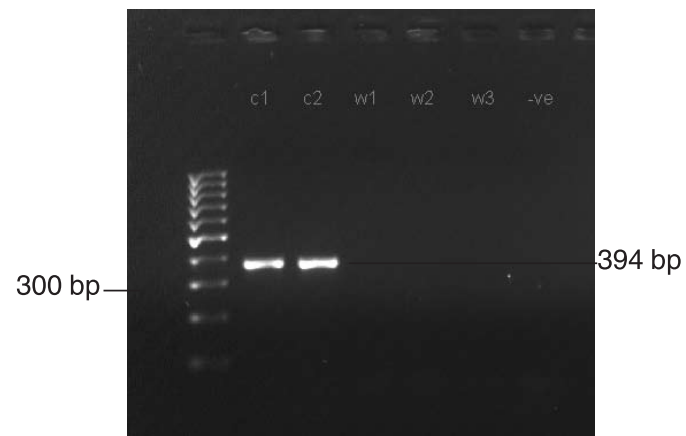

Fig. 5. Agarose gel electrophoresis of $c \operatorname{lmA}$ specific PCR

Lane1: DNA marker 100bp

Lane 2.3: Positive samples (394 bp)

Lane 4-6: Negative samples

\section{Conclusion}

Among 200 cloacal samples of exotic pigeons tested for salmonellosis from 24 lofts, five positive isolates could be obtained. The study showed a prevalence of 2.5 per cent of salmonellosis among exotic pigeons with 16.67 per cent of the lofts affected. The antimicrobial sensitivity tests revealed that all the five isolates positive for salmonellosis were sensitive to amoxicillin-clavulanate and all were resistant to tetracycline and streptomycin. The same revealed that 60 per cent of the positive isolates were sensitive to co-trimoxazole, chloramphenicol, ampicillin, cefoperazone, amikacin and gentamicin.

\section{Acknowledgement}

The authors duly acknowledge the Kerala Veterinary and Animal Sciences University for the facilities provided.

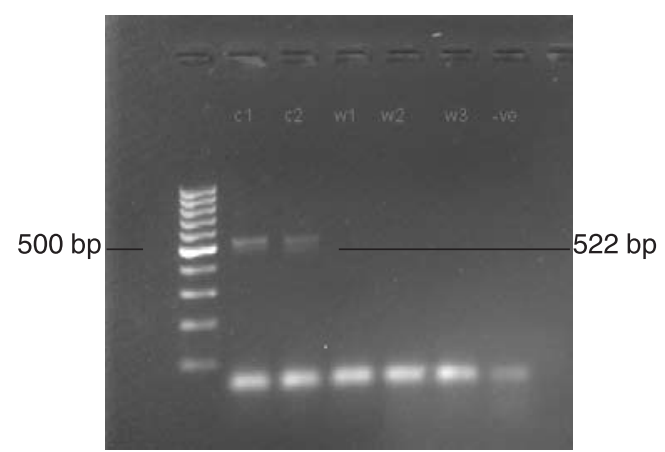

Fig. 4. Agarose gel electrophoresis of aadA2 specific PCR

Lane1: DNA marker 100bp

Lane 2.3: Positive samples (522 bp)

Lane 4-6: Negative samples

\section{Conflict of interest}

The authors declare that they have no conflict of interest.

\section{References}

Arcangioli, M.A., Leroy-Sétrin, S., Martel, J.L. and Chaslus-Dancla, E. 1999. A new chloramphenicol and florfenicol resistance gene flanked by two integron structures in Salmonella typhimurium DT104. FEMS. Microbiol. Lett. 174:327332.

Briggs, C.E.and Fratamico, P.M.1999. Molecular characterization of an antibiotic resistance gene cluster of Salmonella Typhimurium DT104. Antimicrob. Agents Chemother. 43:846-849.

Casanovas, L., De Simon, M., Ferrer, M.D., Arques, J. and Monzon, G. 1995. Intestinal carriage of campylobacters, salmonellas, yersinias and listerias in pigeons in the city of Barcelona. J. Appl. Bact. 78:11-13.

Chen, S., Zhao, S., White, D.G., Schroeder, C.M., Lu, R., Yang, H., McDermott, P.F., Ayers, S. and Meng, J. 2004. Characterization of multiple-antimicrobial-resistant Salmonella serovars isolated from retail meats. Appl. Environ. Microbiol. 70:1-7.

Edward, P. R. and Ewing, W. H. 1986. Edward and Ewing's Identification of Enterobacteriaceae.(4 ${ }^{\text {rd }}$ Ed.) Elsevier Publishing Co. Inc. New York. 463p.

El-Prince, E., Hussein, M.F. and Abd ElRahman, A.M. 2019. Incidence of 
Salmonella species in table eggs and some egg-based products. J. Adv. Vet. Res. 9:1-7.

García, C., Soriano, J.M., Benítez, V. and Catalá-Gregori, P. 2011. Assessment of Salmonella spp. in feces, cloacal swabs, and eggs (eggshell and content separately) from a laying hen farm. Poultry Sci. 90:1581-1585.

Hosain, M.S., Islam, M.A., Khatun, M.M. and Dey, R.K. 2012. Prevalence and antibiogram profiles of Salmonella isolated from pigeons in Mymensingh, Bangladesh. Microbes Hith. 1:54-57.

Jahantigh, M. and Nili, H. 2010. Drug resistance of Salmonella spp. isolated from pigeon eggs. Comp. Clin. Path. 19:437-439.

Kaczorek-Lukowska, E., Sowińska, P., Franaszek, A., Dziewulska, D., Małaczewska, J. and Stenzel, T. 2020. Candomesticpigeonbeapotentialcarrier of zoonotic Salmonella? Transbound. Emerg. Dis. 1-13p DOI: 10.1111/ tbed.13891

Kozak, G.K., Pearl, D.L., Parkman, J., ReidSmith, R.J., Deckert, A. and Boerlin, P. 2009. Distribution of sulfonamide resistance genes in Escherichia coli and Salmonella isolates from swine and chickens at abattoirs in Ontario and Quebec, Canada. Appl. Environ. Microbiol. 75:5999-6001.

Perez-Sancho, M., García-Seco, T., Porrero, C., García, N., Gomez-Barrero, S., Cámara, J.M., Domínguez, L. and Álvarez, J. 2020. A ten-year-surveillance program of zoonotic pathogens in feral pigeons in the City of Madrid (2005-2014): The importance of a systematic pest control. Res. Vet. Sci. 128:293-298.

Rahman, M.M., Rahman, M.M., Meher, M.M., Khan, M.S.I. and Anower, A.M. 2016. Isolation and antibiogram of Salmonella spp. from duck and pigeon in Dinajpur, Bangladesh. J. Adv. Vet. Anim. Res. 3:386-391.

Rajagopal, R. and Mini, M. 2013. Outbreaks of salmonellosis in three different poultry farms of Kerala, India. Asian Pac. J. Trop. Biomed. 3:496-500.

Ranjbar, V.R., Basiri, S. and Abbasi-Kali, R. 2020. Paratyphoid infection caused by
Salmonella Typhimurium in a pigeon flock (Columbia livia) in Iran. J. Zoonotic Dis. 35-39.

Saifullah, M.K., Mamun, M.M., Rubayet, R.M., Nazir, K.N.H., Zesmin, K. and Rahman, M.T. 2016. Molecular detection of Salmonella spp. isolated from apparently healthy pigeon in Mymensingh, Bangladesh and their antibiotic resistance pattern. J. Adv. Vet. Anim. Res. 3:51-55.

Sharma, J., Kumar, D., Hussain, S., Pathak, A., Shukla, M., Kumar, V.P., Anisha, P.N., Rautela, R., Upadhyay, A.K. and Singh, S.P. 2019. Prevalence, antimicrobial resistance and virulence genes characterization of nontyphoidal Salmonella isolated from retail chicken meat shops in Northern India. Food Control. 102:104-111.

Stenzel, T., Bancerz-Kisiel, A., Tykalowski, B., Smialek, M., Pestka, D. and Koncicki, A. 2014. Antimicrobial resistance in bacteria isolated from pigeons in Poland. Pol. J. Vet. Sci.17:169-171.

Teske, L., Ryll, M., Rubbenstroth, D., Hänel, I., Hartmann, M., Kreienbrock, L. and Rautenschlein, S. 2013. Epidemiological investigations on the possible risk of distribution of zoonotic bacteria through apparently healthy homing pigeons. Avian Pathol. 42:397-407.

Xu, F., Min, F., Wang, J., Luo, Y., Huang, S., Chen, M., Wu, R. and Zhang, Y. 2020. Development and evaluation of a Luminex xTAG assay for sulfonamide resistance genes in Escherichia coli and Salmonella isolates. Mol. Cell. Probes. 49:101476.

Yang, S.J., Park, K.Y., Seo, K.S., Besser, T.E., Yoo, H.S., Noh, K.M., Kim, S.H., Kim, S.H., Lee, B.K., Kook, Y.H. and Park, Y.H. 2001. Multidrug-resistant Salmonella Typhimurium and Salmonella Enteritidis identified by multiplex PCR from animals. J. Vet. Sci. 2:181-188.

Yousef, S. and Mamdouh, R. 2016. Class I Integron and $\beta$-lactamase encoding genes of multidrug resistance Salmonella isolated from pigeons and their environments. Cell. Mol. Biol.62:4854. 